READERS' OPINION AND DISCUSSION

OPINION

\section{Lymnaea cousinni (Gastropoda: Lymnaeidae) as transmitter of fascioliasis}

\section{S Mas-Coma}

\author{
Departamento de Parasitología, Facultad de Farmacia, \\ Universidad de Valencia, Av. Vicent Andres Estelles s/n, 46100 \\ Burjassot - Valencia, Spain
}

\section{Dear Editor,}

In the article entitled "First report of Lymnaea cousini Jousseaume, 1887 naturally infected with Fasciola hepatica (Linnaeus, 1758) (Trematoda: Digenea) in Machachi, Ecuador" recently published by Angel Villavicencio A and Mauricio Carvalho de Vasconcellos in Memorias do Instituto Oswaldo Cruz (vol. 100, issue 7, pages 735-737, November 2005), it is stated that their finding in Ecuador represents the first report of specimens of this lymnaeid species naturally infected by the liver fluke. However, it is well known from long ago that this species acts as intermediate host of fascioliasis in Andean countries. In the first half of the last century, Brumpt et al. (1939-1940) already demonstrated that $L$. bogotensis Pilsbry, 1935, a synonym of L. cousini proposed and established by Hubendick (1951) and always accepted (see Pointier et al. 2004), even also recognized by Villavicencio and Carvalho de Vasconcellos (2005) in their paper here in question, is the intermediate host of Fasciola hepatica in the surroundings of Santa Fé de Bogotá, Colombia.

Materials studied by Villavicencio and Carvalho de Vasconcellos (2005) were from Machachi, in the Andean region of Ecuador. These authors further note that fascioliasis prevalence in humans in the Andean region of Ecuador ranges from 24 to $53 \%$ and add the reference of the Servicio Ecuatoriano de Sanidad Animal (SESA 2003) concerning this information. However, these very high human prevalences do not fit with results obtained in surveys carried out up to the present in Andean communities of Ecuador, in which human prevalences always appear to be low or very low: $6 \%$ by serology (Trueba et al. 2000); $0.5 \%$ by coprology (Gozalbo et al. 2004). Authors additionaly note that, according to WHO (1995), almost 200,000 people in Ecuador are infected, but it shall be clarified that these WHO data were only estimations available at the beginning of the 90 s decade.

Villavicencio and Carvalho de Vasconcellos (2005) emphasize the high prevalence of infection of $31.43 \%$ by $F$. hepatica they detected in $L$. cousini snails as the

Email: S.Mas.Coma@uv.es highest value ever reported for lymnaeid snails naturally infected with this parasite. However, although this prevalence is evidently high when compared to current prevalences by fasciolids in lymnaeid snails, which are usually less than $5 \%, F$. hepatica prevalences in snails similar and even higher than that reported by Villavicencio and Carvalho de Vasconcellos (2005) have been found elsewhere. In fascioliasis human endemic areas of Andean countries, for instance, a confirmed $31.6 \%$ prevalence by $F$. hepatica in Galba truncatula was detected in the center of the Northern Bolivian Altiplano village of Tambillo (Bargues et al. 1995), that is, even in a human settlemen instead of in a field place inhabited by livestock.

The fasciolid prevalence reported by Villavicencio and Carvalho de Vasconcellos (2005) was found in $70 \mathrm{~L}$. cousini snail specimens collected in a $4.5-\mathrm{m}^{2}$ area they covered in a private farm of Machachi. Unfortunately, nothing is mentioned about the crowding of the cattle nor about the seasonal managament of cows and fascioliasis prevalences of cattle in that farm. Information on all these aspects is crucial to explain the probable concentration of higly infected cattle for water drinking in the water body these authors studied, as to be able to deduce whether this high prevalence is only the result of a peculiar private farm situation in a given moment of the year or it may be more largely extrapolated, as to evaluate the real epidemiological significance of $L$. cousini in fascioliasis transmission in Ecuador.

There is finally also concern about the acceptance of this prevalence as really and only belonging to $F$. hepatica. The doubts appear after analyzing the results of Brumpt et al. (1939-1940), who stated that the lymnaeid species here in question appears to be a mollusc of low parasitic efficacy for $F$. hepatica, owing to its very low fasciolid infection percentages, and that this lymnaeid additionally shows to develop the role of intermediate host for other trematode species. Villavicencio and Carvalho de Vasconcellos (2005) do not mention how they microscopically classified the fluke larval stages and the only colour photograph included in the paper showing a redia and a cercaria does not allow to ascertain their specific ascription. It is well known that $F$. hepatica larval stages are very similar to those of other digenean species (i.e., bird trematodes). That is why the classification of fasciolid larval stages found in nature always needs a verification, usually made by experimental infection of a definitive host (whether a laboratory model or a domestic herbivore livestock species) and subsequent species classification by microscopical study of mounted trematode adult specimens. Another wellknown way is by studying the cercarial chaetotaxy (Richard 1971), although nowadays molecular tools as rDNA ITS-2 and ITS-1 sequences are also available for direct application to the larval stages (Mas-Coma et al. 2001).

\section{REFERENCES}

Bargues MD, Oviedo JA, Mas-Coma S 1995. Infestaciones experimentales y naturales por Fasciola hepatica (Linnaeus, 1758) (Trematoda: Fasciolidae) en Lymnaea sp. (Gastropoda: Lymnaeidae) del Altiplano Norte boliviano. In IV Congreso Ibérico de Parasitología (Santiago de Compostela, Spain, 24- 
28 July 1995), Libro de Resúmenes, Secretaría del Congreso edit., Santiago de Compostela, Biología p. 139-140.

Brumpt E, Velasquez J, Ucroz H, Brumpt LCh 1939-1940. Mission E. Brumpt et L.-Ch. Brumpt en Colombie et au Venezuela. 1.- Découverte de l'hôte intermédiaire, Limnaea bogotensis Pilsbry, de la grande douve, Fasciola hepatica, en Colombie. Ann Parasitol Hum Comp 17: 563-579.

Gozalbo M, Trueba G, Fornasini M, Fuentes MV, Bargues MD, Esteban JG, Mas-Coma S 2004. Coproparasitological survey in schoolchildren from the community of Planchaloma (Province of Cotopaxi, Ecuador). In S Mas-Coma, MD Bargues, JG Esteban, MA Valero (eds), Multidisciplinarity for Parasites, Vectors and Parasitic Diseases, IX European Multicolloquium of Parasitology (EMOP 9), Programme and Abstracts, J. Aguilar S.L., Valencia, Spain, Abstract No. 874: 447 (Spanish version in Enfermedades Emergentes, 6, 3, No. 84: 170).

Hubendick B 1951. Recent Lymnaeidae. Their Variation, Morphology, Taxonomy, Nomenclature, and Distribution. Kungliga Svenska Vetenskapsakademiens Handlingar, Fjärde Serien, 3 (1): 1-223 + 5 pl.

Mas-Coma S, Funatsu IR, Bargues MD 2001. Fasciola hepatica and lymnaeid snails occurring at very high altitude in South America. Parasitology 123: S115-S127.

Pointier JP, Noya O, Amarista M, Theron A 2004. Lymnaea cousini Jousseaume, 1887 (Gastropoda: Lymnaeidae): first record for Venezuela. Mem Inst Oswaldo Cruz, 99: 567-569.

Richard J 1971. La chétotaxie des cercaires. Valeur systématique et phylétique. Mémoires du Muséum National d'Histoire Naturelle, Paris, Nouv. Sér., Sér. A, Zool., 47: 1-179.

Trueba G, Guerrero T, Fornasini M, Casariego I, Zapata S, Ontaneda S, Vasco L 2000. Detection of Fasciola hepatica infection in a community located in the Ecuadorian Andes. Am J Trop Med Hyg 62: 518.

Villavicencio A, Carvalho de Vasconcellos M 2005. First report of Lymnaea cousini Jousseaume, 1887 naturally infected with Fasciola hepatica (Linnaeus, 1758) (Trematoda: Digenea) in Machachi, Ecuador. Mem Inst Oswaldo Cruz 100: 735-737.

World Health Organization 1995. Control of foodborne trematode infections. WHO Technical Report Series 849: 1-157.

\section{REPLY}

In his short note entitled "Lymnaea cousini (Gastropoda: Lymnaeidae) as transmitter of fascioliasis", written as a consequence of our article "First report of Lymnaea cousini Jousseaume, 1887 naturally infected with Fasciola hepatica (Linnaeus, 1758) (Trematoda: Digenea) in Machachi, Ecuador" recently published in Memorias do Instituto Oswaldo Cruz (vol. 100, issue 7, pages 735-737, November 2005), S Mas-Coma contributes not only to clarify and/or update the knowledge concerning the relationships of the above-mentioned lymnaeid species and fascioliasis, but in fact he is moreover posing questions about scientific research and publication of results in international impact journals.

Many of the aspects emphasized by S Mas-Coma are related to old or very old literature which unfortunately is not available in most of the developing countries, nor in the internet. Sometimes, a literature lapsus is not so important, but when it deals with aspects of systematics and taxonomy as is the present case of the synonymy between $L$. cousini and L. bogotensis and its consequences, or about first findings published long time ago or in publications not easily available for a non-specialist or young researcher, it is evident that they should be taken into account. However, one would also await that evaluators in such high impact international journals, presuposed to be specialists in the field selected by the editor, develop their role by contributing to avoid such situations. Our experience with highly recognized experts is that they are usually overwhelmed and, therefore, do not dispose of the sufficient time to evaluate a paper as needed. And if they refuse to evaluate because of lack of availability, editors are in need to request collaboration by non-experts, a delicate situation when the editor is neither an expert on the field capable to take decissions by himself alone. At any rate, in our case, it appears that at least it is the first finding of snails of the species $L$. cousini to be found naturally infected in Ecuador.

Another aspect rised by S Mas-Coma concerns the frequent differences between reports by experts (i.e., the World Health Organization) and local agencies of developing countries as ministries, national services, etc. In Ecuador, the Animal Health Service of Ecuador (SESA 2003) registers fascioliasis reports in all of the ten provinces of the country, but there is no information about the geographical origin or farms where the infected animals come from. This is due to the fact that animals killed in sloughterhouses do not bear any identification, despite this disease being well known for veterinary physicians working in provinces.

In our article we reported what we thought to be the highest fascioliasis prevalence detected in naturally infected lymnaeids. Although there may be previous reports on higher prevalences, this does not mean that the prevalence we found was extremely high. Another question by Mas-Coma refers to the need of verifying the belonging of the trematode larval stages found to the species Fasciola hepatica, because of the described capacity of $L$. cousini to transmit other trematode species (Brumpt et al. 1939-1940). Although not mentioned in our article, the classification of these larval stages was preliminarily established by morphology of rediae and cercariae in the Fiocruz Department of Biology and confirmation was obtained by experimental infection of laboratory mice by cercariae shed by the collected snails in Petri dishes during 5 days exposure to $4 \mathrm{~h}$ natural light per day. Flukes with morphology of $F$. hepatica were found in the liver after 35 days postinfection with 20 metacercariae per mouse (metacercaeriae conserved for 10 days at $10^{\circ} \mathrm{C}$ ).

However, we would like to emphasize the suggestion of Mas-Coma about the possibility to use cercarial chaetotaxy for the specific classification of the fluke larval stages. Such a method could be very useful for centres of developing countries in which costful techniques as DNA sequencing or laboratory animal keeping are usually not available. 
Similarly as already emphasized by Mas-Coma basing on the data of Brumpt et al. (1939-1940), very low infection results $(0.6 \%)$ and low infection rates $(34 \%)$ in the same lymnaeid species $(L$. cousini $=L$. bogotensis) were also reported in Colombia by Muñoz-Rivas (1953) and more recently noted by Salazar et al. (2006), respectively, suggesting that this lymnaeid may not be a good vector. Consequently, the high fascioliasis prevalence in $L$. cousini snails collected shall be linked to the very high number of cattle living in the farm studied. At the moment of snail collection, there were 10 adult bovines/ha/year which is largely more than the rate of 2 adult bovines/ha/year recommended for the Andean region. Moreover, the $90 \%$ fascioliasis prevalence found in 20 cattle individuals analyzed in that farm is undoubtedly very high, although similar to those found in other farms of Mejia county (Villavicencio 2006). Additional studies on $L$. cousini snails present in farms not only of the province of Pichincha but also from other provinces are needed to get an appropriate assessment of the potential vector role of this lymnaeid in Ecuador.

\section{REFERENCES}

Brumpt E, Velasquez J, Ucroz H, Brumpt LCh 1939-1940. Mission E. Brumpt et L.-Ch. Brumpt en Colombie et au Venezuela. 1.- Découverte de l'hôte intermédiaire, Limnaea bogotensis Pilsbry, de la grande douve, Fasciola hepatica, en Colombie. Ann Parasitol Hum Comp 17: 563-579.
Muñoz-Rivas G 1953. Fasciolosis experimental. Revista de la Academia Colombiana de Ciencias Exactas, Físicas y Naturales 9: 156-158.

Salazar L, Estrada VE, Velásquez L 2006. Effect of the exposure to Fasciola hepatica (Trematoda: Digenea) on life history traits of Lymnaea cousini and Lymnaea columella (Gastropoda: Lymnaeidae). Exp Parasitol 114: 77-83.

SESA 2003. Estadísticas Anuales de Control Epidemiológico, Servicio Ecuatoriano de Sanidad Animal, Quito, 90 pp.

Villavicencio A 2006. Análisis Epizootológico de Fascioliasis (Fasciola hepática, L. 1758) en Ecuador, PhD Thesis, People's Friendship University of Russia, Moscow, 149 pp. (in Russian).
MC de Vasconcellos Departamento de Biologia Instituto Oswaldo Cruz-Fiocruz Rio de Janeiro, RJ, Brasil

Angel Villavicencio A Departament of Veterinary Oathology, Russian People's

Friendship University, Moscow-Russia 
